\title{
A meta-analytical study on the association of human resource management practices with financial, market and operational performance
}

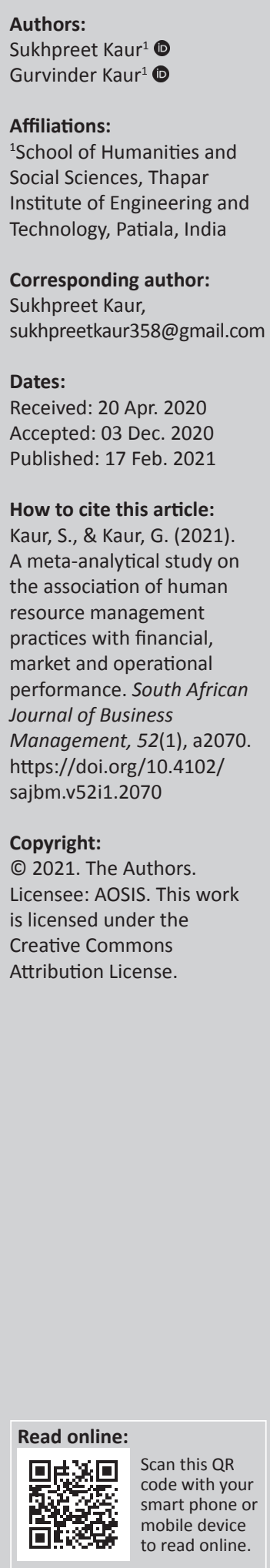

Purpose: This article draws on the meta-analysis technique to systematically analyse and compare the association of human resource management (HRM) practices with financial, market and operational performance.

Design/methodology/approach: An exhaustive search of HRM-performance link resulted in a final sample $(k)$ of 24 independent studies. For this purpose, Comprehensive Meta-Analysis (Version 3.0) software was used. Heterogeneity of the studies was determined using Q-statistic with a $p$-value, $I^{2}, T^{2}$ and Tau. As the degree of heterogeneity was very high, random effects model was selected to estimate the mean of effects. Lastly, publication bias was studied using graphical and statistical methods.

Findings/results: The results revealed the average correlational $(r)$ association of HRM practices with financial performance, market performance and operational performance as $0.305,0.434$ and 0.311 , respectively. More specifically, HRM practices have the strongest association with market performance.

Practical implications: The results statistically quantify the association between HRM practices and organisational performance measures for developing desired knowledge, skills and abilities to generate higher and improved performance. The results of this study provide HR managers with evidence that right investment in human resources does significantly contribute to the bottom line; they should make better and higher allocation of the resources for HRM.

Originality/value: To the best of our knowledge, this study is the first to meta-analytically examine the varying association of HRM with three distinct organisational performance measures.

Keywords: HRM; meta-analysis; comprehensive meta-analysis software; firm performance; financial performance; market performance; operational performance; HRM-firm performance link.

\section{Introduction}

Starting in the 1990s, the first studies statistically analysed the linkage between human resource management (HRM) practices and organisation performance (Arthur, 1994; Becker \& Gerhart, 1996; Becker \& Huselid, 1998; Huselid, 1995; MacDuffie, 1995; Welbourne \& Andrews, 1996). An increasing number of HRM scholars have attempted to establish that human resource practices (HRPs) lead to better organisation performance (Guest, 2011; Katou \& Budhwar, 2007; Singh, 2004; Tzafrir, 2005). Another argument is that the so-called high-performance work practices (HPWPs) in strategic HRM (SHRM) can improve organisation performance by developing employees' competencies, increasing their knowledge and commitment (Appelbaum, Bailey, Berg, \& Kalleberg, 2000). High-performance work practices are a distinct but mutually related set of HRM policies and practices rather than isolated individual HRM practices (Becker \& Huselid, 1998; Huselid, 1995). Even though the association is much discussed in the literature, there are certain issues that have remained untouched so far.

Meta-analysis can be described as a set of statistical procedures designed to collect research results across studies to estimate the relationship between variables in the population as a whole (Glass, 1997). Researchers are increasingly using meta-analysis to aggregate the results of empirical studies on key organisation outcomes, such as recruitment, selection, training and job 
attitudes (Stone \& Rosopa, 2017). In the words of Stone and Rosopa (2017, p. 3), the following are the advantages of using meta-analysis:

- Results of meta-analysis can provide better estimates of the relation in the population than single studies.

- The precision and validity of estimates can be improved as more data are used in a meta-analysis, and the increased amount of data increases the statistical power to detect an effect.

- Inconsistencies in results across studies can be analysed, and the bases for these differences can be analysed (e.g. publication bias, differences in the representativeness of samples).

- Hypothesis testing can be applied on summary estimates.

Till date, meta-analysis on HRM and organisational behaviour has been conducted on the following topics: collective turnover (Hancock, Allen, \& Soelberg, 2017), task performance (Chiaburu, Oh, Wang, \& Stoverink, 2017), employee effectiveness (Mackay, Allen, \& Landis, 2017), performance ratings (Harari \& Rudolp, 2017), recruitment and job-choice (Kristof-Brown, Zimmerman, \& Johnson, 2005) and longitudinal performance analysis (Saridakis, Lai, \& Cooper, 2017). Some recent meta-analytical studies on HRM conveyed the results of its relationship with firm performance across the public, private and semi-public sector (e.g. Blom, Kruyen, Heijden, \& Thiel, 2018). However, studies highlighting meta-analytical mechanism by applying objective measures for assessing the strength of HRM practices in various types of firm performance are still scarce. This study is an attempt to partially fill this gap. Given the widespread use of meta-analysis in the field, the goal of this study is to systematically analyse and compare the association of HRM practices with financial, market and operational performance using a meta-analytical approach. This article aims at contributing to the debate on diverse characteristics of HRM-performance link (Boselie, Dietz, \& Boon, 2005; Guest, Paauwe, \& Wright, 2012; Paauwe, 2009).

\section{Literature review}

This section begins by highlighting the core issues surrounding HRM-performance link. Literature review is sub-divided under three perspectives: (1) financial performance, (2) market performance and (3) operational performance. It should be taken into consideration that there are no hard and fast criteria to categorise the organisational performance under these categories. However, three broad perspectives have been undertaken to avoid any potential overlap.

\section{Human resource management-performance link}

Barney (1991) argues that any firm can procure technology, finance and information, whereas competitive advantage can be achieved only through unique contribution of human capital in the firm. The resource-based approach is directly linked with employee's skills and abilities and capabilities which together encompass the firm's pool of human capital
(Lado \& Wilson, 1994). Pfeffer (1994) suggested 16 best practices for explaining HRM-performance linkage. It is reasoned that a greater use of these practices (training and development, participation and employment, information sharing and some others) would lead to improved productivity and profitability, thus helping organisations in achieving a competitive advantage (Darwish, Singh, \& Mohamed, 2013). According to previous empirical research, the most common types of organisational performance measures are (1) financial or accounting performance, (2) market performance and (3) operational performance (Brealey, Myers, \& Marcus, 2001; Carton \& Hofer, 2006; Penman, 2001). Human resource practices influence HR-based outcomes, followed by financial, market and organisational outcomes. The rationale behind this proposition is that HRPs have a direct impact on employee behaviour, which increases job satisfaction, which in turn helps to generate high financial and organisational outcomes (Dyer \& Reeves, 1995). Studies on HRM-performance link suggest that HR practices enhance organisation performance (Delaney \& Huselid, 1996; Guerrero \& Didier, 2004; Guest, 1997; Guest, Michie, Conway, \& Sheehan, 2003; Lee, Lee, \& Wu, 2010; Lee, Phan, \& Chan, 2005; Panayotopoulou, Bourantas, \& Papalexandris, 2003; Pfeffer, 1994; Richard \& Johnson, 2001; Sels et al., 2006b; Zhang \& Li, 2009).

\section{Human resource management and financial performance}

Considering the association between HRM and financial performance measures, Venkatraman and Ramanujam (1986) emphasised the use of simple outcome-based indicators that are supposed to suggest the fulfilment of the economic goals of the firm. High financial performance has been associated with HRPs which may improve employee behaviour and attitude towards strengthening the competitive strategy of the firm (Hiltrop, 1996). High correlations have been observed between HRPs and profits amongst banks (Delery \& Doty, 1996). Return on assets (ROA), sales growth and valuation of stocks have been linked with HR orientations and measured by effective recruitment and selection of workers and employees (Lam \& White, 1998). Fitz-Enz (1997) identified three paradoxes about best HRM practices: (1) complex business problems have to be solved by employees and managers in the most simplistic manner, (2) considering a visible programme in a journal as best or general practice and (3) following the learnings of past studies for future directions. For instance, some HRPs may be related to financial performance whilst others may be related to staff earning (Lau \& Ngo, 2004). According to Wright and McMahan (1992), the main concern was whether or how firms should benefit from their future source of profitability to achieve a firm competitive advantage. Rogers and Wright (1998) examined 29 studies that provided 80 effect sizes (i.e. described statistical relationships between HRM practices and performance measures) on the HRM-performance link surveying. Amongst the studies surveyed by Rogers and Wright (1998), a few had examined human resource outcomes, whereas several had used accounting and financial market 
measures; the greatest number of effect sizes, however, was seen for organisational outcomes. Hence, we hypothesise that:

H1: HRM practices have strong association with financial performance.

\section{Human resource management and market performance}

Data on market performance are most objective as they comprise of numbers and can be easily obtained even if the size of the investigation is large. On the contrary, whilst viewing the subjective side of HRM-market performance linkage, perceived market performance is utilised in cases where obtaining objective data is uncertain. Specific market performance indicators are market value, market share and revenue (Byremo, 2015). Zhang and Li (2009) studied the association between HPWPs and market performance in the Chinese pharmaceutical industry. Human resource practices, such as detailed job descriptions, performance appraisals, training and development programmes and profit-sharing, were found to be significantly associated with the company's perceived market results. Considering the criticism about accounting-based performance measures, several authors have proposed market-based performance measures (e.g. McGuire, Schneeweis, \& Hill, 1986). Various studies have found a positive correlation between HRM practices and market performance measures (Azmi, 2010; Behery, 2011; Katou \& Budhwar, 2010). Hence, we hypothesise that:

H2: HRM practices have strong association with market performance.

\section{Human resource management and operational performance}

Ahmad and Schroeder (2003) studied the effectiveness of seven HRM practices suggested by Pfeffer (1998), focusing on measuring the effects of these practices on operations. The seven HRM practices include compensation/incentive contingent on performance, selective hiring, use of teams and decentralisation, employment security, status differences, extensive training and sharing information. Operational performance consists of cost, quality, flexibility, delivery and organisational commitment. Their study overall supported the relationship between the seven HRM practices and operational performance. Chang and Chen (2002) evaluated the relationship between HRM practices and firm performance of Taiwanese high-tech firms. It was found that HRM practices, such as teamwork, training and development, performance appraisal, human resource planning and employee benefits, have a significant effect on employee productivity. Human resource planning and benefits are negatively related to employee turnover. Huselid, Jackson and Schuler (1997) investigated the effect of HRM practices on firm performance of 293 US firms. They divided HRM effectiveness into two types. The first type was HRM effectiveness, which included recruitment and training, compensation, industrial/employee relations, appraisal, selection tests and employee attitudes. The second type was SHRM effectiveness that comprised teamwork, employee participation and empowerment, employee and manager communications and management and executive development. Their study revealed that there was a positive association between SHRM effectiveness and firm performance. However, they found that technical HRM effectiveness was not related to firm performance. MacDuffie (1995) carried out research on 62 automotive assembly plants to recognise the effect of HRM bundles on operational performance and proposed that innovative HRM bundles affected operational performance.

Three mediators through which HRM practices affect organisational performance function are (1) increasing employee's knowledge, skill and abilities (KSAs), (2) empowering employees to act and (3) motivating them (Becker \& Huselid, 1998). These mediators affect employee discretionary effort, creativity and productivity (Becker, Huselid, Pickus, \& Spratt, 1997). As a result, operating performance measures, such as job satisfaction and employee turnover (Dyer \& Reeves, 1995), transform into improved accounting returns (Becker et al., 1997; Dyer \& Reeves, 1995; Huselid, 1995). According to Dyer and Reeves (1995), HRM practices should affect operational performance such as productivity and retention more than financial measures such as accounting returns and growth. Despite the fact that HRM practices affect both operational and financial set of measures, operational performance measures are relatively closer to behavioural developments employees are expected to make. Improved financial results apart from HRM practices are caused by a wide variety of factors, such as acquisition or diversification activity (O'Shaughnessy \& Flangan, 1998). This results in more variability in accounting returns, market returns and growth. Human resource management practices indicate a smaller portion of the above variability (Combs, Liu, Hall, \& Ketchen, 2006). As a result, the relationship between HRM practices and operational performance measures like productivity and turnover should be stronger as compared to financial performance measures. Hence, we hypothesise that:

H3: HRM practices have strong association with operational performance.

\section{Method Search strategy}

To identify potential studies that investigate the statistical association between HRM practices and organisational performance, empirical studies were searched during April and May 2019. To identify relevant studies, empirical studies published from January 2000 to March 2019 were searched. As all studies were considered as potentially relevant, no limit was set on the search period. Databases from EBSCO, Web of Science (WoS), Education Research Information Center (ERIC) and Social Science Research Network (SSRN) were used for this purpose. Search strings included the following keywords: 'HRM', 'Human Resource', 'HR Practice', 'HR Policy', 'High Performance Work Practices', 'HPWP', 'Personnel Practices', 'Personnel Policies', 'Financial Performance', 'Market Performance' and 'Operational Performance'. In total, 9423 potentially 


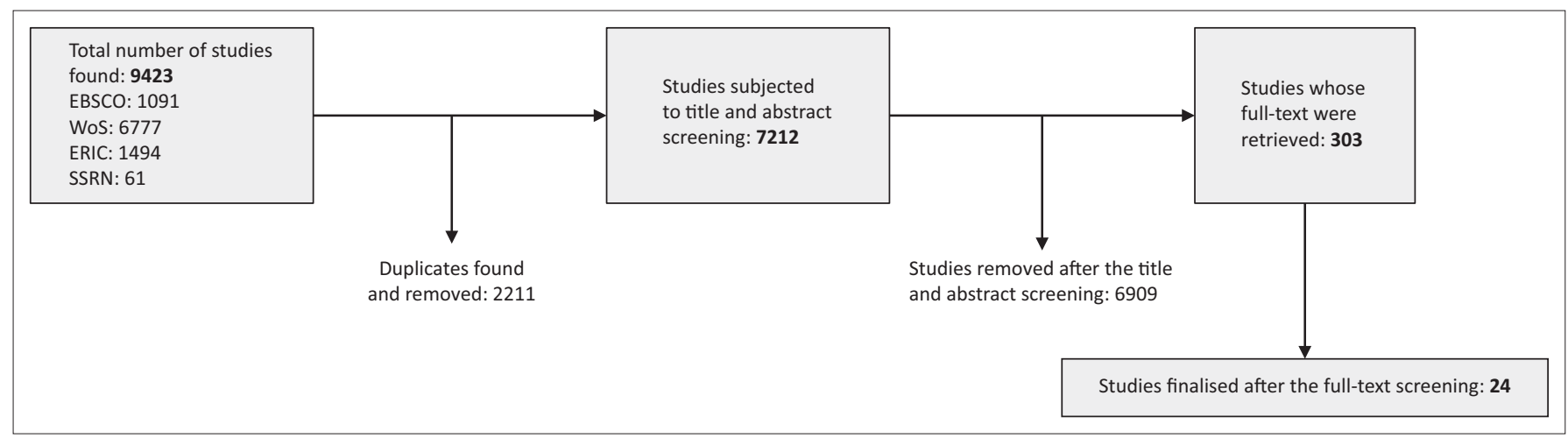

FIGURE 1: Identification of relevant studies. EBSCO, Elton B. Stephens Company; WoS, Web of Science; ERIC, Education Research Information Center; SSRN, Social Science Research Network.

useful studies were identified using these keywords. We have treated each association as independent. After applying the inclusion criteria, 24 studies (Bae, Chen, Wan, Lawler \& Walumbwa, 2003; Beh \& Loo, 2013; Björkman \& Xiucheng, 2002; Chang \& Huang, 2005; Chang \& Xin, 2009; Chuang \& Liao, 2010; Darwish et al., 2013; Ferguson \& Reio, 2010; Fey, Björkman, and Pavlovskaya, 2000; Fu, Bosak, Flood \& Ma, 2018; Gong,Green, Wu, Whitten \& Medlin, 2006; Gurbuz \& Mert, 2011; Katou, 2017; Li, Qin, Jiang, Zhang, \& Gao, 2015; Ngo \& Loi, 2008; Park, Mitsuhashi, \& Björkman, 2003; Sels et al., 2006; Singh, 2003; Singh 2004; Wan, Ong, \& Kok, 2002; Wei \& Lau, 2008; Wei \& Lau, 2010; Wright, Gardner, \& Moynihan, 2003; Zhang \& Morris, 2014) were selected. Figure 1 shows the search and selection criteria for relevant studies. In addition, several papers (Arthur, 1994; Becker \& Gerhart, 1996; Becker \& Huselid, 1998; Guest, Michie, Sheehan, \& Conway, 2000; Guest et al., 2012; Huselid, 1995; Welbourne \& Andrews, 2014) on the association between HRM and organisational performance were also studied to advance our knowledge about this relationship. However, these papers were eventually not included in the metaanalysis.

\section{Inclusion criteria}

Only those studies which met the following inclusion criteria were included in our meta-analysis. Firstly, only studies published in English were included. Secondly, only journals/academic journals were searched for necessary studies. Thirdly, only studies which provided correlations for the association between HRM and organisation performance were searched. However, no differentiation was made between studies using self-rated or any other measure for understanding this linkage. Finally, only studies that provide necessary statistical information (sample size and correlation coefficient) needed to perform the meta-analysis were included.

\section{Meta-analysis technique}

Hak, Van Rhee and Suurmond (2018) suggest meta-analysis as a systematic technique for synthesising quantitative results of different empirical studies regarding the effect of an independent variable on a defined outcome. The metaanalysis was done using Comprehensive Meta-Analysis
(Version 3.0) software developed by Biostat. Borenstein, Cooper, Hedges and Valentine (2009) suggested that the estimates of correlation parameter $p$ are mere sample correlation coefficient, $r$. The variance of $\mathrm{r}$ is approximately

$v_{r}=\frac{\left(1-r^{2}\right)^{2}}{n-1}$

[Eqn 1]

where $n$ is the sample size, as shown in Equation 1.

Generally, synthesis on the correlation coefficient is avoided because the variance strongly depends on the correlation. When studies report correlation values, the values of the correlation are themselves used as effect size. The correlation values are converted into Fisher's $z$ scale, and all the analyses are done using converted values (see Eqn 2).

The transformation from correlation to Fisher's $z$ is

Fisher's $z=0.5 \times \log \left(\frac{1+\text { Correlation }}{1-\text { Correlation }}\right)$

[Eqn 2]

Another key aspect is to determine the degree of homogeneity of the studies included in the meta-analysis. It helps in determining the statistical model to be used (Mills, 2009). Population estimates are better for effect sizes based on larger samples than those based on smaller samples (Lipsey \& Wilson, 2001). According to Hak et al. (2018), heterogeneity of the studies is determined by the following: $Q$-statistic with a $p$-value, $I^{2}, T^{2}$ and Tau. The Q-statistic (also known as Cochran's Q) gives the measure of variation around the average but not heterogeneity. It is estimated to study whether the variability across effect sizes is greater than expected from sampling error alone. $I^{2}$ is a relative measure for the proportion observed variance that suggests real differences in the effect size. If $I^{2}$ is low, the degree of homogeneity is high amongst the selected studies. However, higher $I^{2}$ suggests that selected studies cannot be considered as belonging to the same population. Value of $I^{2}$ statistic with $0 \%$ implies no heterogeneity, $50 \%$ implies moderate heterogeneity and $75 \%$ or more implies high heterogeneity (Higgins, Thompson, Deeks, \& Altman, 2003). As $I^{2}$ is more than $95 \%$ in the studies used for meta-analysis here, it cannot be considered as studies belonging to the same population. Together, $T^{2}$ and Tau are measures of dispersion of true effect sizes between studies in terms of the effect size. Tau is an 
estimate of the standard deviation of the distribution of true effect sizes, whereas $T^{2}$ is an estimate of the variance of true effect sizes (Hak et al., 2018).

When the mean effect size is homogenous (i.e. nonsignificant $Q$-statistic), it indicates that the dispersion of the effect sizes around the mean is less than or equal to the sampling error. Under this condition, the fixed effects model is used. However, when the effect size is heterogeneous (i.e. significant $Q$-statistic), the random effects model is used (Shelby \& Vaske, 2008). Fixed effects model assumes that there is one true size which is shared by the studies included for metaanalysis, whereas random effects model assumes that the true effect size varies from study to study.

According to Berkeljon and Baldwin (2014), random effects models make statistical inferences about the population of studies which are not included in the meta-analysis. After observing the degree of homogeneity, random effects model was selected to estimate the mean of effects. It avoids the underestimation of weights of a small study or overestimation of the weight of a large study (Borenstein et al., 2009).

Lastly, the set of studies selected for meta-analysis is likely to be biased in many ways. Publication bias refers to the tendency of taking studies with significant studies. The field of publication bias has been broader than estimated. Following are some forms of publication bias categories: reporting bias, language bias, database bias, prestige bias and redundant publication bias (Rothstein, Sutton, \& Borenstein, 2005). The main purpose of analysing publication bias is to analyse the potential publication bias in selected studies (Hak et al., 2018). Funnel plot is one of the most common mechanisms for showing the relationship between study size and effect size. Apart from funnel plot, there are certain statistical analysis techniques which reveal publication bias in meta-analytical investigation: (1) classic fail-safe $N$, (2) Begg and Mazumdar rank correlation, (3) Duval and Tweedie's trim and fill method and (4) Egger's regression intercept (Borenstein, Hedges, Higgins, \& Rothstein, 2011).

\section{Results}

Weighted average association between HRM practices and organisational performance measures is estimated with the random effects model in Table 1 . To judge the magnitude of product-moment correlation coefficient effect size, correlation effect size values are considered small if less than or equal to 0.10 , medium, if equal to 0.25 and large, if greater than or equal to 0.40 (Lipsey \& Wilson, 2001).
Answering to H1, 17559 respondents and 12 independent studies gave an average correlation of 0.305 (95\% confidence interval $[\mathrm{CI}]=0.175$ to 0.424$)$. Visual inspection revealed that the funnel plot is relatively symmetric (see Figure 2). As the funnel plot is largely subjective, various statistical tests have been performed. The classic fail-safe $N$ indicated that 2037 missing studies were needed to bring the $p$-value above the $\alpha$ level $(\alpha=0.05)$. Following Duval and Tweedie's trim and fill method, no missing studies were located to the left of the mean. However, two missing studies were found to the right of the mean. This changed the point estimate from 0.315 to $0.364(95 \% \mathrm{CI}=0.177$ to 0.452 to $95 \% \mathrm{CI}=0.194$ to 0.535$)$. Egger's regression test showed that the intercept varied from zero $\left(\mathrm{B}_{0}=3.749 ; 95 \% \mathrm{CI}=-2.983\right.$ to 10.483 ; $p($ one-tailed $)=0.122 ; p$ [two-tailed $]=0.243)$, thus indicating asymmetry in the included studies. The average correlation for association between HRM practices and financial performance (0.305) is lower than the average correlation for association between HRM practices and market performance (0.434). However, it is also lower than the average correlation for association between HRM practices and operational performance $(0.311)$. Therefore, H1 is rejected.

Answering to H2, 5745 respondents and 16 independent studies provided an average correlation of 0.434 (95\% $\mathrm{CI}=0.173-0.638)$. Visual inspection revealed that the funnel plot is considerably asymmetric. The direction of the effect is towards the right, thereby creating a gap on left, where the nonsignificant studies would have been if they had been located (see Figure 3). The classic fail-safe $N$ suggested that 3075 missing studies were needed to raise the $p$-value above the arbitrary $\alpha$ level $(\alpha=0.05)$. Duval and Tweedie's trim and fill method showed no missing studies to the left of the mean. However, two missing studies were found to the right of the mean. This shifted the point estimate from 0.465

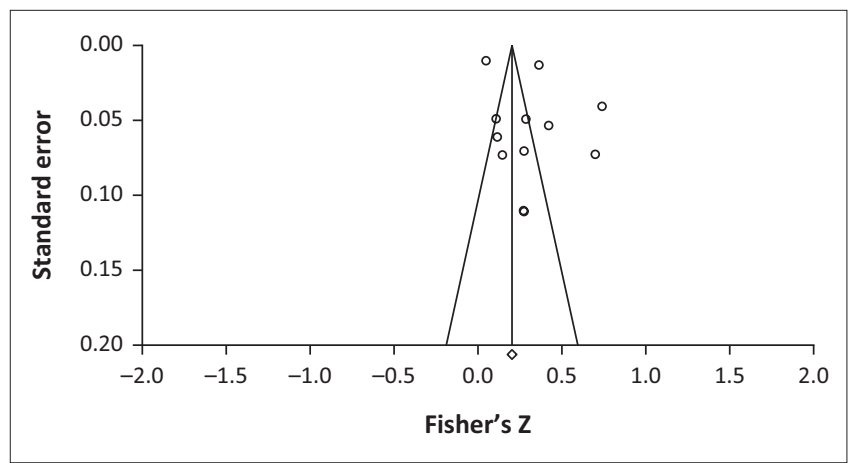

FIGURE 2: Funnel plot depicting publication bias for the association between human resource management and financial performance.

\begin{tabular}{|c|c|c|c|c|c|c|c|c|c|c|}
\hline Hypothesis & $N$ & $k$ & $r$ & $z$ & $\begin{array}{c}95 \% \mathrm{Cl} \\
\text { (under random } \\
\text { effects model) }\end{array}$ & $Q_{\text {within }}$ & $I^{2}$ & $T$ & $T^{2}$ & $p$ \\
\hline H1: Financial performance & 17559 & 12 & 0.305 & 4.483 & $0.175-0.424$ & 609.538 & 98.195 & 0.234 & 0.055 & $<0.05$ \\
\hline H2: Market performance & 5745 & 16 & 0.434 & 3.139 & $0.173-0.638$ & 1626.352 & 99.078 & 0.587 & 0.344 & $<0.05$ \\
\hline H3: Operational performance & 7346 & 6 & 0.311 & 2.030 & $0.011-0.559$ & 415.542 & 98.797 & 0.380 & 0.145 & $<0.05$ \\
\hline
\end{tabular}

$N$, total sample size; $k$, number of studies in meta-analysis; $r$, average weighted correlation coefficient; $95 \% \mathrm{Cl}$, lower and upper limits of $95 \%$ confidence interval. 


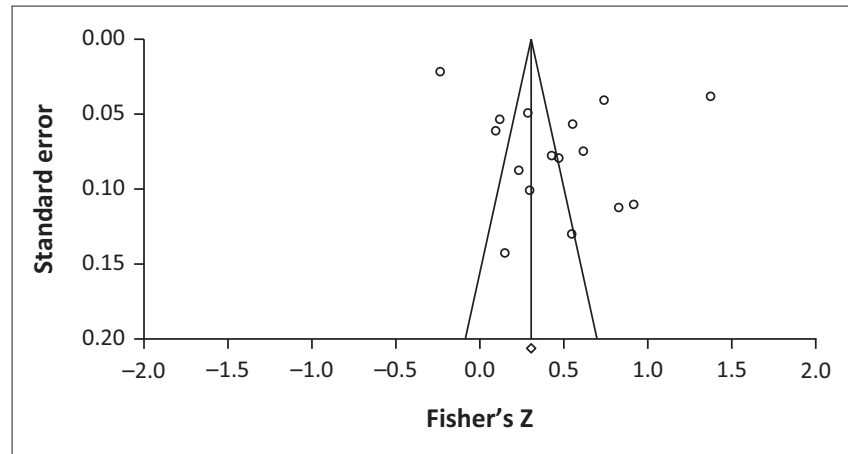

FIGURE 3: Funnel plot depicting publication bias for the association between human resource management and market performance.

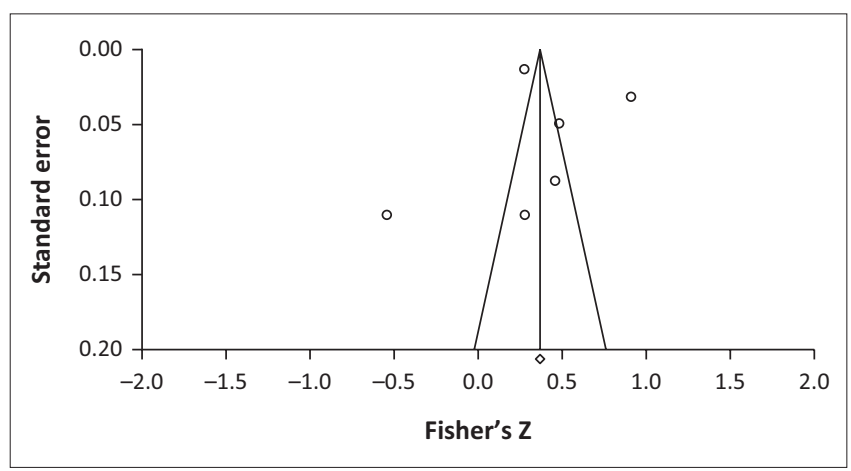

FIGURE 4: Funnel plot depicting publication bias for the association between human resource management and operational performance.

to $0.543(95 \% \mathrm{CI}=0.175$ to 0.756 to $95 \% \mathrm{CI}=0.222$ to 0.863$)$. Egger's regression test showed that the intercept varied from zero $\left(\mathrm{B}_{0}=7.283 ; 95 \% \mathrm{CI}=-3.522\right.$ to $18.089 ; p$ [onetailed] $=0.085 ; p$ [two-tailed] $=0.170)$, thus signifying asymmetry in the selected studies. The average correlation for the association between HRM practices and market performance (0.434) was higher than the average correlation for the association between HRM practices and financial performance $(0.305)$. It was also higher than the average correlation for the association between HRM practices and operational performance $(0.311)$. Therefore, $\mathrm{H} 2$ is fully supported.

Answering to H3, 7346 respondents and six independent studies gave an average correlation of 0.311 (95\% CI = 0.011-0.559). The funnel plot revealed studies as almost equal distribution around the mean (see Figure 4). The classic failsafe $N$ suggested that 1001 missing studies were needed to bring the $p$-value above the $\alpha$ level $(\alpha=0.05)$. Duval and Tweedie's trim and fill method found two missing studies to the left of the mean. However, no missing studies were found to the right of the mean. This shifted the point estimate from 0.321 to 0.124 (95\% CI $=0.011$ to 0.638 to $95 \% \mathrm{CI}=-0.254$ to 0.503). Egger's regression test showed that the intercept varied from zero $\left(\mathrm{B}_{0}=1.716 ; 95 \% \mathrm{CI}=-15.449\right.$ to 18.881 ; $p$ [one-tailed] $=0.398 ; p$ [two-tailed] $=0.795)$, thus signifying asymmetry in the selected studies. The average correlation for the association between HRM practices and operational performance (0.311) was higher than the average correlation for the association between HRM practices and financial performance (0.305). However, it was lower than the average correlation for the association between HRM practices and market performance (0.434). Therefore, H3 is partially supported. H1 and H3 predict that HRM practices have a moderately strong association with financial performance $(r=0.35)$ and with operational performance $(r=0.311)$, respectively. $\mathrm{H} 2$ predicts that $\mathrm{HRM}$ practices have a strong impact market performance $(r=0.434)$. Most importantly, the difference is significant $(p<0.05)$, suggesting that the effect of HRM practices on financial, market and operational performance measures is statistically significant. Our findings show that HRM practices positively affect organisational performance measures and thus largely influence market performance.

\section{Discussion}

The goal of this meta-analysis was to analyse and compare the association between HRM practices and financial, market and operational performance. To the best of our knowledge, this work is first to meta-analytically examine the varying association of HRM with three organisational performance measures, thereby contributing to the debates on the importance of context for HRM-performance linkage (Paauwe, 2009; Vermeeren, 2014). In contrast to what we expected, there seems only a small difference between the association of HRM with financial and operational performance measures. As all relevant studies were included for initial search, there is a variety of issues like goal ambiguity, personnel constraints and cultural context in which those studies were conducted.

Our study does not specify the HRM practices which affect the organisational performance; it simply studies the correlation between HRM practices and various performance measures. Traditionally, financial performance measures were the first choice of academicians for analysing the effect of HRM practices on organisational performance (MacDuffie \& Kochan, 1995; Uysal, 2008). This is evident as more than $55 \%$ studies of the sample population are on HRMorganisational financial performance linkage. However, with the changing business scenario, the emphasis has shifted to market performance. Market performance matches the external business environment with important financial areas in the organisation, thus providing a roadmap for an efficient utilisation of the corporate resources (Çetin \& Oğuz, 2010). This change is strongly supported by statistical results as the highest correlation $(r=0.434)$ is observed between HRM-market performance. The findings of the study extend the applicability of SHRM and work as an evidence for the adoption of HRM practices for improving market performance. The results support a universal context for the applicability of HRM practices in improving firm performance, especially market performance relationship (Guest, 1997). There are many ways to understand the association of HRM practices on firm performance, however adopting meta-analytical procedure provides robust estimate by aggregating information leading to an accurate statistical power. Each 
organisation must review its strategies, goals, objectives and operations because changes in HRM policies and practices influence organisational performance. In addition to the main results, this meta-analysis has two noteworthy findings. First, the results, at least statistically, quantify the association between HRM practices and organisational performance measures for developing desired knowledge, skills and abilities to generate higher and improved performance. Second, the results of this study provide HR managers with evidence that right investment in human resources does significantly contribute to the bottom line; they should make better and higher allocation of the resources for HRM.

\section{Conclusion}

In addition to the main results, this meta-analysis has two noteworthy findings. Firstly, the results, at least statistically, quantify the association between HRM practices and organisational performance measures for developing desired knowledge, skills and abilities to generate higher and improved performance. Secondly, the results of this study provide HR managers with evidence that right investment in human resources does significantly contribute to the bottom line; they should make better and higher allocation of the resources for HRM.

Similar to other studies, this study has certain limitations which must be acknowledged. The search for the studies to be included for the current meta-analysis was restricted to academic journals/journals. Including grey literature might have offered more resources. A majority of the studies which measured the association between HRM practices and organisational performance used the same rate source. This could lead to common method bias which could overstate the correlational values. Future studies are encouraged to explain the choice of HRM practices considered in the individual studies as inclusion criteria. This will improve the reliability of results. Moderator analysis was not performed as it would further result in relatively fewer studies for the meta-analysis.

On lines of this research, future researchers are expected to examine and compare this association on sectoral context. Although not explicitly stated in the inclusion criteria, all studies selected for meta-analysis happen to be cross-sectional. This further limits our conclusions. Researchers are encouraged to include longitudinal study designs as well for high-quality research. Also, it would be worthwhile to adopt a qualitative or case study approach for the association between HRM practices and various organisational performance measures. This study would thus be supplemented with meta-synthesis and/or realist synthesis. In conclusion, this literature review helps in statistically highlighting the association between HRM practices and organisational performance. It has been noted that:

[T] he behaviour of large and complex aggregates... is not to be understood in terms of a simple extrapolation of the properties of a few ... instead, at each level of complexity entirely new properties appear. (Anderson, 1972, p. 393)

Similarly, this study suggests that for different performance measures, HR managers should take a different approach. The aim of every organisation should be to efficiently deal with the complexities which come in the way of improving organisational performance.

\section{Acknowledgements Competing interests}

The authors declare that they have no financial or personal relationships that may have inappropriately influenced them in writing this research article.

\section{Authors' contributions}

S.K. and G.K. contributed equally to this research article.

\section{Funding information}

This research received no specific grant from any funding agency in the public, commercial or not-for-profit sectors.

\section{Ethical consideration}

This article followed all ethical standards for research without direct contact with human or animal subjects.

\section{Data availability}

Data sharing is not applicable to this article as no new data were created or analysed in this study.

\section{Disclaimer}

The views and opinions expressed in this article are those of the authors and do not necessarily reflect the official policy or position of any affiliated agency of the authors.

\section{References}

Ahmad, S., \& Schroeder, R.G. (2003). The impact of human resource management practices on operational performance: Recognizing country and industry differences. Journal of Operations Management, 21(1), 19-43. https://doi.org/ 10.1016/S0272-6963(02)00056-6

Anderson, P.W. (1972). More is different. Science, 177(4047), 393-396. https://doi. org/10.1126/science.177.4047.393

Appelbaum, E., Bailey, T., Berg, P.B., Kalleberg, A.L., \& Bailey, T.A. (2000). Manufacturing advantage: Why high-performance work systems pay off. Ithaca, NY: Cornell University Press.

Arthur, J.B. (1994). Effects of human resource systems on manufacturing performance and turnover. Academy of Management Journal, 37(3), 670-687. https://doi. org $/ 10.2307 / 256705$

Azmi, I.A.G. (2010). Competency-based human resource practices in Malaysian public sector organizations. African Journal of Business Management, 4(2), 235-241. https://doi.org/10.5897/AJBM.9000142

Bae, J., Chen, S.J., David Wan, T.W., Lawler, J.J., \& Walumbwa, F.O. (2003). Human resource strategy and firm performance in Pacific rim countries. The International Journal of Human Resource Management, 14(8), 1308-1332. https://doi. org/10.1080/0958519032000145774

Barney, J. (1991). Firm resources and sustained competitive advantage. Journal of Management, 17(1), 99-120. https://doi.org/10.1177/014920639101700108

Becker, B., \& Gerhart, B. (1996). The impact of human resource management on organizational performance: Progress and prospects. Academy of Management Journal, 39(4), 779-801. https://doi.org/10.2307/256712 
Becker, B.E., Huselid, M.A., Pickus, P.S., \& Spratt, M.F. (1997). HR as a source of shareholder value: Research and recommendations. Human Resource Management, 36(1), 39-47. https://doi.org/10.1002/(SICI)1099-050X(199721) 36:1<39::AID-HRM8>3.0.CO;2-X

Becker, B.E., \& Huselid, M.A. (1998). Human resources strategies, complementarities, and firm performance. New York, NY: SUNY Buffalo.

Beh, L.S., \& Loo, L.H. (2013). Human resource management best practices and firm performance: A universalistic perspective approach. Serbian Journal of Management, 8(2), 155-167.

Behery, M. (2011). High involvement work practices that really count: Perspectives from the UAE. International Journal of Commerce and Management, 21(1), 21-45. https://doi.org/10.1108/10569211111111685

Berkeljon, A., \& Baldwin, S.A. (2014). An introduction to meta-analysis for psychotherapy outcome research. Psychotherapy Research, 19(4-5), 511-518. https://doi.org/10.1080/10503300802621172

Björkman, I., \& Xiucheng, F. (2002). Human resource management and the performance of Western firms in China. International Journal of Human Resource Management, 13(6), 853-864. https://doi.org/10.1080/09585190210134246

Blom, R., Kruyen, P.M., Van der Heijden, B.I., \& Van Thiel, S. (2018). One HRM fits all? A meta-analysis of the effects of HRM practices in the public, semipublic, and private sector. Review of Public Personnel Administration, 4O(1), 3-35.

Borenstein, M., Cooper, H., Hedges, L., \& Valentine, J. (2009). Effect sizes for continuous data. In H. Cooper, L.V. Hedges, \& J.C. Valentine (Eds.), The handbook of research synthesis and meta-analysis vol. 2, pp. 221-235. New York, NY: Russel Sage Foundation.

Borenstein, M., Hedges, L.V., Higgins, J.P., \& Rothstein, H.R. (2011). Introduction to meta-analysis. Hoboken, NJ: John Wiley \& Sons.

Boselie, P., Dietz, G., \& Boon, C. (2005). Commonalities and contradictions in HRM and performance research. Human Resource Management Journal, 15(3), 67-94. https://doi.org/10.1111/j.1748-8583.2005.tb00154.x

Brealey, R.A., Myers, S.C., \& Marcus AJ. (2001). Fundamentals of corporate finance (3rd edn.). New York, NY: McGraw-Hill.

Byremo, C.S. (2015). Human resource management and organisational performance: Does HRM lead to better organisational performance?. Master's thesis. Oslo: University of Oslo.

Carton, R.B., \& Hofer, C.W. (2006). Measuring organizational performance: Metrics for entrepreneurship and strategic management research. Cheltenham: Edward Elgar Publishing.

Çetin, T., \& Oğuz, F. (2010). The effects of economic regulation in the Istanbul taxicab market. Economic Affairs, 30(3), 59-64.

Chang, P.L., \& Chen, W.L. (2002). The effect of human resource management practices on firm performance: Empirical evidence from high-tech firms in Taiwan. International Journal of Management, 19(4), 622-631. https://doi.org/10.1080/ 095851900339963

Chang, W.J.A., \& Huang, T.C. (2005). Relationship between strategic human resource management and firm performance: A contingency perspective. Internationa Journal of Manpower, 26(5), 434-449. https://doi.org/10.1108/01437720510615125

Chiaburu, D.S., Oh, I.S., Wang, J., \& Stoverink, A.C. (2017). A bigger piece of the pie: The relative importance of affiliative and change-oriented citizenship and task performance in predicting overall job performance. Human Resource Management Review, 27(1), 97-107. https://doi.org/10.1016/j.hrmr.2016.09.006

Chuang, C.H., \& Liao, H.U.I. (2010). Strategic human resource management in service context: Taking care of business by taking care of employees and customers. Personnel Psychology, 63(1), 153-196. https://doi.org/10.1111/j.1744-6570.2009. 01165.x

Combs, J., Liu, Y., Hall, A., \& Ketchen, D. (2006). How much do high-performance work practices matter? A meta-analysis of their effects on organizational performance. Personnel Psychology, 59(3), 501-528. https://doi.org/10.1111/j.1744-6570. 2006.00045.x

Darwish, T.K., Singh, S., \& Mohamed, A.F. (2013). The role of strategic HR practices in organisational effectiveness: An empirical investigation in the country of Jordan. The International Journal of Human Resource Management, 24(17), 3343-3362. https://doi.org/10.1080/09585192.2013.775174

Delaney, J.T., \& Huselid, M.A. (1996). The impact of human resource management practices on perceptions of organizational performance. Academy of Management Journal, 39(4), 949-969. https://doi.org/10.2307/256718

Delery, J.E., \& Doty, D.H. (1996). Modes of theorizing in strategic human resource management: Tests of universalistic, contingency, and configurational performance predictions. Academy of Management Journal, 39(4), 802-835. https://doi.org/ 10.5465/256713

Dyer, L., \& Reeves, T. (1995). Human resource strategies and firm performance: What do we know and where do we need to go? International Journal of Human Resource Management, 6(3), 656-670. https://doi.org/10.1080/09585199500000041

Ferguson, K.L., \& Reio, Jr. T.G. (2010). Human resource management systems and firm performance. Journal of Management Development, 29(5), 471-494. https://doi. org/10.1108/02621711011039231

Fey, C.F., Björkman, I., \& Pavlovskaya, A. (2000). The effect of human resource management practices on firm performance in Russia. International Journa of Human Resource Management, 11(1), 1-18. https://doi.org/10.1080/ 095851900339963

Fitz-Enz, J. (1997). The truth about best practices: What they are and how to apply them. Human Resource Management (1986-1998), 36(1), 97. https://doi org/10.1002/(SICI)1099-050X(199721)36:1<97::AID-HRM16>3.0.CO;2-B
Fu, N., Bosak, J., Flood, P.C., \& Ma, Q. (2018). Chinese and Irish professional service firms compared: Linking HPWS, organizational coordination, and firm performance. Journal of Business Research, 95(1), 266-276. https://doi.org/ 10.1016/j.jbusres.2018.08.021

Glass, G.V. (1977). Integrating findings: The meta-analysis of research. Review of Research in Education, 5(1), 351-379. https://doi.org/10.2307/1167179

Gong, Y., Law, K.S., Chang, S., \& Xin, K.R. (2009). Human resources management and firm performance: The differential role of managerial affective and continuance commitment. Journal of Applied Psychology, 94(1), 263. https://doi.org/10.1037/ a0013116

Green, K.W., Wu, C., Whitten, D., \& Medlin, B. (2006). The impact of strategic human resource management on firm performance and HR professionals' work attitude and work performance. The International Journal of Human Resource Management, 17(4), 559-579. https://doi.org/10.1080/09585190600581279

Guerrero, S., \& Didier, V. (2004). High-involvement practices and performance of French firms. The International Journal of Human Resource Managment, 15(8), 1408-1423. https://doi.org/10.1080/0958519042000258002

Guest, D.E. (1997). Human resource management and performance: A review and research agenda. International Journal of Human Resource Management, 8(3), 263-276. https://doi.org/10.1080/095851997341630

Guest, D.E. (2011). Human resource management and performance: Still searching for some answers. Human Resource Management Journal, 21(1), 3-13. https://doi. org/10.1111/j.1748-8583.2010.00164.x

Guest, D.E., Michie, J., Conway, N., \& Sheehan, M. (2003). Human resource management and corporate performance in the UK. British Journal of Industria Relations, 41(2), 291-314. https://doi.org/10.1111/1467-8543.00273

Guest, D.E., Michie, J., Sheehan, M., \& Conway, N. (2000). Getting inside the HRM performance relationship. Paper presented at the Academy of Management Conference (pp. 1-15), Toronto.

Guest, D.E., Paauwe, J., \& Wright, P. (Eds.). (2012). HRM and performance Achievements and challenges. Hoboken, NJ: John Wiley \& Sons.

Gurbuz, S., \& Mert, I.S. (2011). Impact of the strategic human resource management on organizational performance: Evidence from Turkey. The International Journal of Human Resource Management, 22(8), 1803-1822. https://doi.org/10.1080/09 585192.2011.565669

Hak, T., Van Rhee, H., \& Suurmond, R. (2018). How to interpret results of metaanalysis (version 1.3). Rotterdam: Erasmus Rotterdam Institute of Management. Retrieved from https://www.erim.eur.nl/fileadmin/erim content/images/metaessentials/How_to_interpret_results_of_meta-analysis_1.4.pdf.

Hancock, J.I., Allen, D.G., \& Soelberg, C. (2017). Collective turnover: An expanded meta-analytic exploration and comparison. Human Resource Management Review, 27(1), 61-86. https://doi.org/10.1016/j.hrmr.2016.06.003

Harari, M.B., \& Rudolph, C.W. (2017). The effect of rater accountability on performance ratings: A meta-analytic review. Human Resource Management Review, 27(1), 121-133. https://doi.org/10.1016/j.hrmr.2016.09.007

Higgins, J.P., Thompson, S.G., Deeks, J.J., \& Altman, D.G. (2003). Measuring inconsistency in meta-analyses. BMJ, 327(7414), 557-560. https://doi.org/ 10.1136/bmj.327.7414.557

Hiltrop, J.M. (1996). The impact of human resource management on organisational performance: Theory and research. European Management Journal, 14(6), performance: Theory and research. European Management

Huselid, M.A. (1995). The impact of human resource management practices on turnover, productivity, and corporate financial performance. Academy of Management Journal, 38(3), 635-672. https://doi.org/10.2307/256741

Huselid, M.A., Jackson, S.E., \& Schuler, R.S. (1997). Technical and strategic human resource management effectiveness as determinants of firm performance. Academy of Management Journal, 40(1), 171-188. https://doi.org/10.2307/ 257025

Katou, A.A. (2017). How does human resource management influence organisationa performance? An integrative approach-based analysis. International Journal of Productivity and Performance Management, 66(6), 797-821. https://doi.org/ 10.1108/IJPPM-01-2016-0004

Katou, A.A., \& Budhwar, P.S. (2007). The effect of human resource management policies on organizational performance in Greek manufacturing firms. Thunderbir International Business Review, 49(1), 1-35. https://doi.org/10.1002/tie.20129

Katou, A.A., \& Budhwar, P.S. (2010). Causal relationship between HRM policies and organisational performance: Evidence from the Greek manufacturing sector.
European Management Journal, 28(1), 25-39. https://doi.org/10.1016/j.emj. European Mand

Kristof-Brown, A.L., Zimmerman, R.D., \& Johnson, E.C. (2005). Consequences of individuals' fit at work: A meta-analysis of person-job, person-organization, person-group, and person-supervisor fit. Personnel Psychology, 58(2), 281-342. person-group, and person-supervisor fit. Personne
https://doi.org/10.1111/j.1744-6570.2005.00672.x

Lado, A.A., \& Wilson, M.C. (1994). Human resource systems and sustained competitive advantage: A competency-based perspective. Academy of Management Review, 19(4), 699-727. https://doi.org/10.2307/258742

Lam, L.W., \& White, L.P. (1998). Human resource orientation and corporate performance. Human Resource Development Quarterly, 9(4), 351-364. https:// doi.org/10.1002/hrdq.3920090406

Lau, C.M., \& Ngo, H.Y. (2004). The HR system, organizational culture, and product innovation. International business Review, 13(6), 685-703. https://doi.org/ 10.1016/j.ibusrev.2004.08.001

Lee, F.H., Lee, T.Z., \& Wu, W.Y. (2010). The relationship between human resource management practices, business strategy and firm performance: Evidence from steel industry in Taiwan. The International Journal of Human Resource Management, 21(9), 1351-1372. https://doi.org/10.1080/09585192.2010.488428 
Lee, S.H., Phan, P.H., \& Chan, E. (2005). The impact of HR configuration on firm performance in Singapore: A resource-based explanation. The International Journal of Human Resource Management, 16(9), 1740-1758. https://doi.org/ Journal of Human Resource

Li, X., Qin, X., Jiang, K., Zhang, S., \& Gao, F.Y. (2015). Human resource practices and firm performance in China: The moderating roles of regional human capital quality and firm innovation strategy. Management and Organization Review, 11(2), 237-261. https://doi.org/10.1017/mor.2015.12

Lipsey, M.W., \& Wilson, D.B. (2001). Practical meta-analysis. Thousand Oaks, CA: Sage.

MacDuffie, J.P. (1995). Human resource bundles and manufacturing performance: Organizational logic and flexible production systems in the world auto industry. ILR Review, 48(2), 197-221. https://doi.org/10.1177/001979399504800201

MacDuffie, J.P., \& Kochan, T.A. (1995). Do US firms invest less in human resources? Training in the world auto industry. Industrial Relations: A Journal of Economy and Society, 34(2), 147-168. https://doi.org/10.1111/j.1468-232X.1995. tb00366.x

Mackay, M.M., Allen, J.A., \& Landis, R.S. (2017). Investigating the incremental validity of employee engagement in the prediction of employee effectiveness: A metaanalytic path analysis. Human Resource Management Review, 27(1), 108-120. https://doi.org/10.1016/j.hrmr.2016.03.002

Mills, L.B. (2009). A meta-analysis of the relationship between emotional intelligence and effective leadership. Journal of Curriculum and Instruction, 3(2), 22.

McGuire, J., Schneeweis, T., \& Hill, J. (1986). An analysis of alternative measures of strategic performance. Advances in Strategic Management, 4(2), 1986.

Ngo, H.Y., \& Loi, R. (2008). Human resource flexibility, organizational culture and firm performance: An investigation of multinational firms in Hong Kong. The International Journal of Human Resource Management, 19(9), 1654-1666. https://doi.org/10.1080/09585190802295082

O'Shaughnessy, K.C. \& Flanagan, D.J. (1998). Determinants of layoff announcements following M\&As: An empirical investigation. Strategic Management Journal, 19(10), 989-999. https://doi.org/10.1002/(SICI)1097-0266(199810)19:10<989: AID-SMJ994>3.0.CO;2-3

Paauwe, J. (2009). HRM and performance: Achievements, methodological issues and prospects. Journal of Management Studies, 46(1), 129-142. https://doi.org/ 10.1111/j.1467-6486.2008.00809.x

Panayotopoulou, L., Bourantas, D., \& Papalexandris, N. (2003). Strategic human resource management and its effects on firm performance: An implementation of the competing values framework. International Journal of Human Resource Management, 14(4), 680-699. https://doi.org/10.1080/0958519032000057781

Park, H.J., Mitsuhashi, H., Fey, C.F., \& Björkman, I. (2003). The effect of human resource management practices on Japanese MNC subsidiary performance: A partial mediating model. The International Journal of Human Resource Management, 14(8), 1391-1406. https://doi.org/10.1080/0958519032000 Managemer
145819

Penman, SH. (2001). Financial statement analysis and security valuation. New York, NY: McGraw-Hill.

Pfeffer, J. (1994). Competitive advantage through people. California Management Review, 36(2), 9.

Pfeffer, J. (1998). Seven practices of successful organizations. California Managemen Review, 40(2), 96-124. https://doi.org/10.2307/41165935

Richard, O.C., \& Johnson, N.B. (2001). Strategic human resource management effectiveness and firm performance. International Journal of Human Resource Management, 12(2), 299-310.

Rogers, E.W., \& Wright, P.M. (1998). Measuring organizational performance in strategic human resource management: Looking beyond the Lamppost. CAHRS Working Paper Series, 135. Ithaca, NY: Cornell University.

Rothstein, H.R., Sutton, A.J., \& Borenstein, M. (2005). Publication bias in meta-analysis In Publication bias in Meta-Analysis: Prevention, assessment and adjustments (pp. 1-7). Chichester: John Wiley \& Sons Ltd.
Saridakis, G., Lai, Y., \& Cooper, C.L. (2017). Exploring the relationship between HRM and firm performance: A meta-analysis of longitudinal studies. Human Resource Management Review, 27(1), 87-96. https://doi.org/10.1016/j.hrmr. Resource Manar
2016.09.005

Singh, K. (2004). Impact of HR practices on perceived firm performance in India. Asia Pacific Journal of Human Resources, 42(3), 301-317. https://doi.org/ 10.1177/1038411104048170

Sels, L., De Winne, S., Maes, J., Delmotte, J., Faems, D., \& Forrier, A. (2006a). Unravelling the HRM-performance link: Value-creating and cost-increasing effects of small business HRM. Journal of Management Studies, 43(2), 319-342. https:// doi.org/10.1007/s11187-004-6488-6

Sels, L., De Winne, S., Delmotte, J., Maes, J., Faems, D., \& Forrier, A. (2006b). Linking HRM and small business performance: An examination of the impact of HRM intensity on the productivity and financial performance of small businesses. Small Business Economics, 26(1), 83-101. https://doi.org/10.1007/s11187-004-6488-6

Singh, K. (2003). Strategic HR orientation and firm performance in India. Internationa Journal of Human Resource Management, 14(4), 530-543. https://doi.org/ 10.1080/0958519032000057574

Shelby, L.B., \& Vaske, J.J. (2008). Understanding meta-analysis: A review of the methodological literature. Leisure Sciences, 30(2), 96-110. https://doi.org/ 10.1080/01490400701881366

Stone, D.L., \& Rosopa, P.J. (2017). The advantages and limitations of using metaanalysis in human resource management research. Human Resource Management Review, 27(1), 1-7. https://doi.org/10.1016/j.hrmr.2016.09.001

Tzafrir, S.S. (2005). The relationship between trust, HRM practices and firm performance. The International Journal of Human Resource Management, 16(9), performance. The International Journal of Human Resource

Uysal, G. (2008). Relationship among HR practices and firm performance: A Turkey context. The Journal of American Academy of Business, 13(2), 112-117.

Venkatraman, N., \& Ramanujam, V. (1986). Measurement of business performance in strategy research: A comparison of approaches. Academy of Management Review, 11(4), 801-814. https://doi.org/10.2307/258398

Vermeeren, B.B. (2014). HRM implementation and performance in the public sector Doctoral thesis. Rotterdam: Erasmus University.

Wan, D., Ong, C.H., \& Kok, V. (2002). Strategic human resource management and organizational performance in Singapore. Compensation \& Benefits Review, 34(4), 33-42. https://doi.org/10.1177/0886368702034004006

Wei, L.Q., \& Lau, C.M. (2008). The impact of market orientation and strategic HRM on firm performance: The case of Chinese enterprises. Journal of International Business Studies, 39(6), 980-995. https://doi.org/10.1057/palgrave.jibs.8400395

Wei, L.Q., \& Lau, C.M. (2010). High performance work systems and performance: The role of adaptive capability. Human Relations, 63(10), 1487-1511. https://doi. org/10.1177/0018726709359720

Welbourne, T.M., \& Andrews, A.O. (1996). Predicting the performance of initial public offerings: Should human resource management be in the equation? Academy of Management Journal, 39(4), 891-919. https://doi.org/10.2307/256716

Wright, P.M., Gardner, T.M., \& Moynihan, L.M. (2003). The impact of HR practices on the performance of business units. Human Resource Management Journal, 13(3) 21-36. https://doi.org/10.1111/j.1748-8583.2003.tb00096.x

Wright, P.M., \& McMahan, G.C. (1992). Theoretical perspectives for strategic human resource management. Journal of Management, 18(2), 295-320. https://doi. org/10.1177/014920639201800205

Zhang, B., \& Morris, J.L. (2014). High-performance work systems and organizational performance: Testing the mediation role of employee outcomes using evidence from PR China. The International Journal of Human Resource Management, 25(1), 68-90. https://doi.org/10.1080/09585192.2013.781524

Zhang, Y.C., \& Li, S.L. (2009). High performance work practices and firm performance: Evidence from the pharmaceutical industry in China. The International Journal of
Human Resource Management, 20(11), 2331-2348. https://doi.org/10.1080/ Human Resource Mand
09585190903239690 